\title{
First records of the Crested Black-Tyrant (Knipolegus lophotes, Tyrannidae) in the State of Mato Grosso do Sul, Brazil
}

\author{
Maurício Neves Godoi ${ }^{1,5}$, Marco de Barros Costacurta ${ }^{4}$, Alessandro Pacheco Nunes ${ }^{1}$, \\ Eduardo Weffort Patrial ${ }^{3}$ \& José Carlos Morante Filho ${ }^{2}$ \\ ${ }^{1}$ Pós-graduação em Ecologia e Conservação, Centro de Ciências Biológicas e da Saúde, \\ Universidade Federal de Mato Grosso do Sul-UFMS, Cidade Universitária, s/n, CP 549, \\ CEP 79070-900, Campo Grande, MS, Brasil \\ ${ }^{2}$ Pós-graduação em Ecologia e Conservação da Biodiversidade, Universidade Estadual de Santa Cruz- \\ UESC, Km 16, Rod. Ilhéus-Itabuna, CEP 45662-900, Ilhéus, BA, Brasil \\ ${ }^{3}$ ONG Meio Ambiente Equilibrado - MAE, Rua Tomazina, 229, Jardim Dom Bosco, \\ CEP 86060-660, Londrina, PR, Brasil \\ ${ }^{4}$ Pós-graduação em Meio Ambiente e Desenvolvimento Regional, \\ Universidade para o Desenvolvimento do Estado e Região do Pantanal - UNIDERP, \\ Rua Ceará, 333, Câmpus I, \\ Bloco II, Bairro Miguel Couto, CEP 79003-010, Campo Grande, MS, Brasil \\ ${ }^{5}$ Corresponding author: Maurício Neves Godoi, e-mail: mauricioecologia@hotmail.com
}

GODOI, M.N., COSTACURTA, M.B., NUNES, A.P., PATRIAL, E.W. \& MORANTE FILHO, J.C. First records of the Crested Black-Tyrant (Knipolegus lophotes, Tyrannidae) in the State of Mato Grosso do Sul, Brazil. Biota Neotrop. 12(3): http://www.biotaneotropica.org.br/v12n3/en/abstract?short-communication+bn01012032012

Abstract: The Crested Black-Tyrant (Knipolegus lophotes) is a member of the Tyrannidae family that occurs throughout open areas in central, southeastern and southern Brazil. Although this species occurs in regions that surround the state of Mato Grosso do Sul, there had never been a recorded sighting in the state. Thus, information on its distribution across Brazil's midwestern region is scarce. In this study, we report the first sightings of K. lophotes in Mato Grosso do Sul. These records extend the known distribution range of the species in midwestern Brazil and contribute to expanding knowledge of bird species composition in this region. We believe that the absence of $K$. lophotes from the lists of bird species recorded in different localities in Mato Grosso do Sul may be a reflection of its local rarity and the lack of bird inventory efforts in this region, which underscores the need for further research into bird communities in this poorly known region of Brazil.

Keywords: birds, Tyrannidae, range extension, Cerrado, mid-western Brazil.

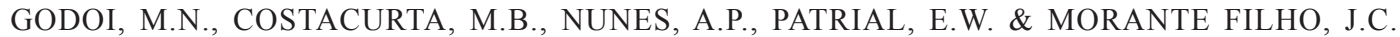
Primeiros registros da maria-preta-de-penacho (Knipolegus lophotes, Tyrannidae) no estado de Mato Grosso do Sul, Brasil. Biota Neotrop. 12(3): http://www.biotaneotropica.org.br/v12n3/pt/abstract?shortcommunication+bn01012032012

Resumo: A Maria-Preta-de-Penacho (Knipolegus lophotes) é um membro da família Tyrannidae que no Brasil ocorre em áreas abertas das regiões sudeste, central e sul. Apesar de ocorrer em regiões próximas ao estado de Mato Grosso do Sul, a espécie nunca foi registrada neste estado, e assim informações sobre sua distribuição no centro-oeste do país são escassas. Neste artigo reportamos os primeiros registros da ocorrência de K. lophotes no Mato Grosso do Sul. Estes registros ampliam a área de distribuição conhecida dessa espécie na região centrooeste do Brasil e contribuem para o conhecimento da avifauna desta região. Acredita-se que o registro recente de $K$. lophotes no Mato Grosso do Sul se deva tanto a sua raridade local quanto a falta de estudos ornitológicos mais amplos no estado, apontando a necessidade da realização de mais estudos nesta região pouco conhecida do país em relação a sua avifauna.

Palavras-chave: aves, Tyrannidae, extensão de distribuição geográfica, Cerrado, centro-oeste do Brasil. 


\section{Introduction}

The Crested Black-Tyrant (Knipolegus lophotes, Boie 1828) is a small member of the Tyrannidae family. It measures $20.5-21 \mathrm{~cm}$, being that the female specimen is larger than the male (Sick 1997). This species occurs in shrubby and semi arboreal fields (known locally as campos sujos and campos cerrados, respectively), dry forests, shrubby riparian formations and rocky fields in mountains (Sick 1997, Sigrist 2009, Grantsau 2010).

Its distribution in South America covers a large portion of Uruguay, northeastern Paraguay and Brazil (Birdlife International 2009), where it occurs in the country's midwestern (State of Mato Grosso), southeastern (Minas Gerais, São Paulo, Espírito Santo and Rio de Janeiro), central (Goiás and Tocantins) and southern regions (Paraná to Rio Grande do Sul) (Ridgely \& Tudor 1994, Sick 1997, Grantsau 2010).

The Crested Black-Tyrant (K. lophotes) occurs over a wide geographic range in central Brazil and has been recorded in regions near the state of Mato Grosso do Sul, such as Emas National Park in the state of Goiás (Hass 2003) and Chapada dos Guimarães in the state of Mato Grosso (Lopes et al. 2009). Although some bird inventories have been conducted in Mato Grosso do Sul, specifically in the Pantanal wetlands (Tubelis \& Tomas 2003), Serra da Bodoquena (Pivatto et al. 2006), Cerrado (Silva et al. 2006), Chaco (Straube et al. 2006) and the Paraná River basin (Gimenes et al. 2007), there has never been any confirmed evidence of the occurrence of $K$. lophotes in the state. Thus, there is a great knowledge gap concerning the geographic distribution of $K$. lophotes across the midwestern region of Brazil, which underscores the need for more detailed information on its occurrence in this region. In this study, we present the first records of $K$. lophotes in the state of Mato Grosso do Sul, expanding knowledge on its geographic distribution in Brazil and contributing to the knowledge of bird composition in a poorly studied region of Brazil.

\section{Materials and Methods}

The data presented here were obtained by means of bird inventories conducted by the authors between 2009 and 2011. The inventories took place near the stream of São Domingos in the town of Caarapó $\left(22^{\circ} 43^{\prime} \mathrm{S}\right.$ and $\left.54^{\circ} 39^{\prime} \mathrm{W}\right)$, Correntes River in the town of Sonora $\left(17^{\circ} 32^{\prime} \mathrm{S}\right.$ and $\left.54^{\circ} 26^{\prime} \mathrm{W}\right)$, and in plateaus in the town of Rio Negro (19 $28^{\prime} \mathrm{S}$ and $\left.54^{\circ} 49^{\prime} \mathrm{W}\right)$. The method used to conduct the surveys was bird census based on direct observation (Rodrigues et al. 2005), which consists of sampling as many habitats as possible through visualization techniques and bird vocalizations during periods of high bird activity, between 06:00 - 10:00 and 15:00 - 18:00 hours. $K$. lophotes individuals were sighted and identified via binoculars and bird identification guides (Ridgely \& Tudor 1994, Sigrist 2009). Whenever possible, individuals were photographed as a means to record their sighting and photos were then uploaded to Wiki Aves (online Encyclopedia of Brazilian Birds). Additional information on each recorded sighting, such as geographic coordinates and type of habitat, were also recorded to better characterize the species' occurrence and distribution in the state of Mato Grosso do Sul.

\section{Results and Discussion}

In this study, we present the first records of $K$. lophotes in the state of Mato Grosso do Sul and expand its known geographic distribution in Brazil. The records were collected from three different localities in the state (Figure 1). On June 18, 2009, one individual was sighted and photographed by Marco Costacurta in the town of Caarapó, located in the southeast region of the state. The specimen, identified as an adult male, was perched on a wire fence in a pasture near the stream

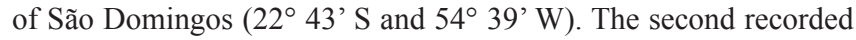
sighting took place in a sugar-cane plantation near the same stream, on the morning of June 19, 2009. On both occasions, Marco Costacurta observed the bird's black plumage and crests and used these features for species identification. The landscape of São Domingos stream is dominated by cultivated pastures, with small fragments of riparian forests and extensive sugar-cane cultivation. Another area of species occurrence in Mato Grosso do Sul is the region of Correntes River, in areas adjacent to the Small Hydro Power Plant Santa Gabriela in the municipality of Sonora $\left(17^{\circ} 32^{\prime} \mathrm{S}\right.$ and $\left.54^{\circ} 26^{\prime} \mathrm{W}\right)$. In this area, Mauricio Godoi sighted $K$. lophotes individuals in February, May and November 2010 (Godoi 2011), and José Carlos Morante Filho sighted individuals in February 2011 (Morante Filho 2011) (Figures 1 and 2). On these occasions, pairs of $K$. lophotes were observed foraging in grasslands and shrubby fields in the margins of Correntes River. This region's landscape is dominated by patches of cerrado stricto sensu, riparian forests and cultivated pastures. Finally, during a brief bird inventory undertaken at Serra de Maracaju in March 2011, Eduardo Patrial sighted and photographed a K. lophotes individual in a shrubby field located in a plateau in the town of Rio Negro $\left(19^{\circ} 28^{\prime} \mathrm{S}\right.$ and $54^{\circ} 49^{\prime} \mathrm{W}$ ) (Figure 1). In this region, the landscape is predominantly dominated by plateaus with cultivated pastures and Cerrado vegetation.

The Crested Black-Tyrant (K. lophotes) is not present in the lists of worldwide endangered species (Birdlife International 2009) or Brazilian endangered species (Silveira \& Straube 2008). This species has a wide geographic distribution in central and southern Brazil, is predominantly insectivore and is mainly found in grasslands and shrubby fields (Willis 1976, Ribeiro et al. 2002), which could favored the expansion in its distribution by consequence of deforestation and the expansion of cultivated pastures in the state of Mato Grosso do Sul. Despite its wide geographic range and preference for open areas, which would make it an easily sighted bird, $K$. lophotes has not been previously sighted in the state of Mato Grosso do Sul.

With regard to the occurrence of congeneric species in Mato Grosso do Sul, at this time the only sight records are for $K$. striaticeps in the town of Corumbá (Naumburg 1930) and K. aterrinus in Bodoquena National Park (Bornschein et al. 2003). Although the distribution maps of K. lophotes in Brazil (Dunning 1987, Ridgely \& Tudor 1994, Sigrist 2009, Gwynne et al. 2010) include a small and isolated area in the state of Mato Grosso do Sul (Pantanal and the southmost region of the state), there are no published records of the species' occurrence in these regions (Straube et al. 1996, Tubelis \& Tomas 2003). Revisions of bird species lists from the town of Coxim (Pinto 1940), high Paraná River wetlands (Gimenes et al. 2007), Serra da Bodoquena (Pivatto et al. 2006) and the state's eastern Cerrado region (Pinto 1932, Silva et al. 2006), indicate no records of $K$. lophotes either.

Published records of $K$. lophotes sightings in midwestern Brazil come mainly from the Distrito Federal region (Braz \& Cavalcanti 2001). However, confirmed sightings of the species in Cerrado regions near Mato Grosso do Sul, such as Emas National Park (Hass 2003) and Chapada dos Guimarães National Park (Lopes et al. 2009), suggest it does occur in the state. Therefore, we believe that the absence of the species from the bird lists of different localities in the state of Mato Grosso do Sul may reflect its local rarity and the lack of bird inventory efforts in this region. This is further reinforced by the fact that recent surveys found other bird species for the first time in the state (Zucca et al. 2007, Faxina et al. 2010, Godoi et al. 2011).

Thus, there is a clear need for more bird inventories in the state of Mato Grosso do Sul that would sample different state regions 

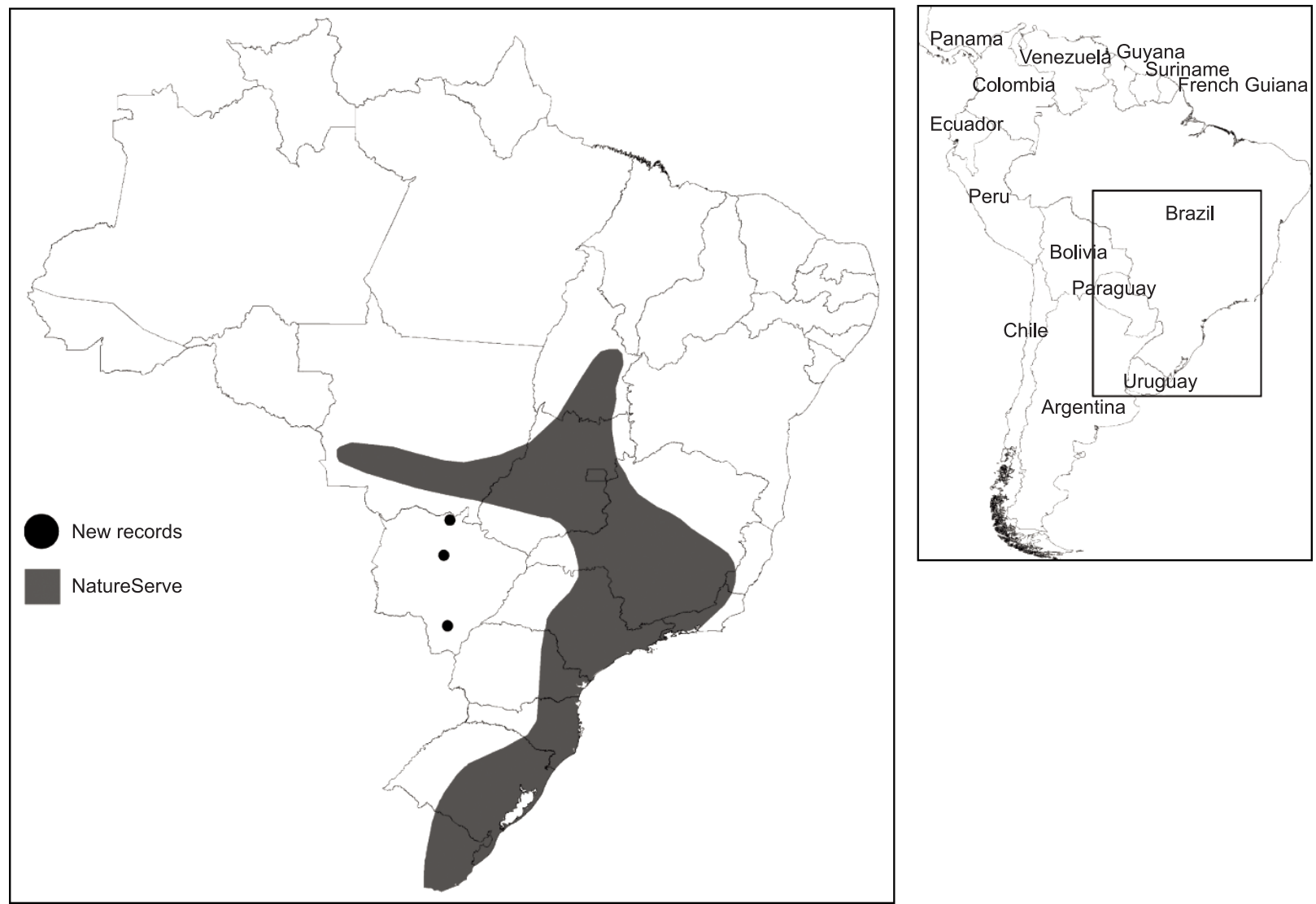

Figure 1. Geographic distribution of the Crested Black-Tyrant (Knipolegus lophotes) in Brazil (according Ridgely \& Tudor 1994) and the records obtained in the state of Mato Grosso do Sul. Image: Roberto Gamarra.

Figura 1. Distribuição geográfica da maria-preta-de-penacho (Knipolegus lophotes) no Brasil (segundo Ridgely \& Tudor 1994) e os registros obtidos no estado de Mato Grosso do Sul. Imagem: Roberto Gamarra.

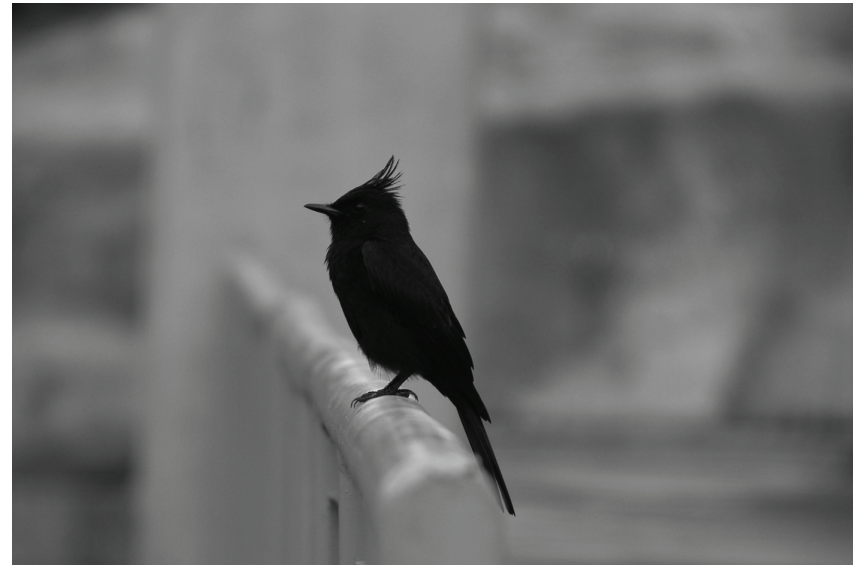

Figure 2. Adult male of the Crested Black-Tyrant (Knipolegus lophotes) photographed in the margins of Correntes river, Sonora county, state of Mato Grosso do Sul. Photo: José Carlos Morante Filho.

Figura 2. Macho adulto da maria-preta-de-penacho (Knipolegus lophotes) fotografado nas margens do rio Correntes, município de Sonora, Mato Grosso do Sul. Foto: José Carlos Morante Filho.

in order to better understand bird composition in the midwestern regions of Brazil, as well as provide more detailed information on the occurrence of different bird species whose distribution is poorly known in this region of the country.

\section{Acknowledgements}

We would like to thank Roberto Gamarra for creating the distribution map and all anonymous reviewers who contributed to the final version of this manuscript. M. N. Godoi and A. P. Nunes also thank the Post-Graduate Program in Ecology and Conservation at Universidade Federal de Mato Grosso do Sul (Federal University of Mato Grosso do Sul) and CAPES (Coordination for the Improvement of Higher Level Personnel) for its postgraduate scholarship awards. Finally, we are very grateful to Rodrigo Neves Godoi, Janaína Ribeiro and Débora Cristina P. S. de Aquino for the final revision of the English version of this manuscript.

\section{References}

BIRDLIFE INTERNATIONAL. 2009. Knipolegus lophotes. In IUCN Red List of Threatened Species (International Union for Conservation of Nature - IUCN 2011). version 2011.2. www.iucn.org.br. (último acesso em 21/05/2012).

BORNSCHEIN, M.R., CÁCERES, N.C., FERREIRA, W.C., FREITAS, D.R. \& PICHORIM, M. 2003. Primeiro registro de Knipolegus aterrinus Kaup, 1853 no Brasil (Tyrannidae). Ararajuba 11(1):141-144.

BRAZ, V.S. \& CAVALCANTI, R.B. 2001. A representatividade de áreas protegidas do Distrito Federal na conservação da avifauna do Cerrado. Ararajuba 9(1):61-69.

DUNNING, J.S. 1987. South American Birds: a photographic aid to identifications. Harrowood Books, Pennsylvania. 
Godoi, M.N. et al.

FAXINA, C., FISCHER, E. \& BENITES, M. 2010. O rei-do-bosque vai além do Pantanal: registros de Pheucticus aureoventris (Cardinalidae) na bacia do Paraná. Rev. Bras. Ornitol. 18(4):349-351.

GIMENES, M.R., LOPES, E.V., LOURES-RIBEIRO, A., MENDONÇA, L.B. \& ANJOS, L. 2007. Aves da planície alagável do alto rio Paraná. Editora da Universidade Estadual de Londrina, Maringá, 281p.

GODOI, M.N. 2011.Wiki Aves - A Enciclopédia das Aves do Brasil. [WA406401, Knipolegus lophotes (Boie, 1828)]. http://www.wikiaves. com.br/406401 (último acesso em 21/05/2012).

GODOI, M.N., CAPEK, M., PIVATTO, M.A.C., LITERAK, I. \& KOKES, J. 2011. Masked Tityra Tityra semifasciata in Mato Grosso do Sul, Brazil. Rev. Bras. Ornitol. 19(3):428-433.

GRANTSAU, R.K.H. 2010. Guia completo para identificação das Aves do Brasil. Vento Verde, São Carlos, v.2, 656p.

GWYNNE, J.A., RIDGELY, R.S., TUDOR, G. \& ARGEL, M. 2010. Aves do Brasil: Pantanal \& Cerrado. Horizonte, São Paulo, 322p.

HASS, A. 2003. Avaliação da avifauna do Parque Nacional das Emas. Plano de Manejo do Parque Nacional das Emas. IBAMA/MMA, Brasília.

LOPES, L.E., PINHO, J.B., BERNARDON, B., OLIVEIRA, F.F., BERNARDON, G., FERREIRA, L.P., VASCONCELOS, M.F., MALDONADO-COELHO, M., NÓBREGA, P.F.A. \& RUBIO, T.C. 2009. Aves da Chapada dos Guimarães, Mato Grosso, Brasil: uma síntese histórica do conhecimento. Pap. Avulsos Zool. 49(2):9-47.

MORANTE FILHO, J.C. 2011. Wiki Aves - A Enciclopédia das Aves do Brasil. [WA315529, Knipolegus lophotes (Boie, 1828)]. http://www. wikiaves.com.br/315529 (último acesso em 21/05/2012).

NAUMBURG, E.M.B. 1930. The Birds of Mato Grosso, Brazil: a report on the birds secured by the RooseveltRondon expedition. Bull. Am. Mus. Nat. Hist. 60:1-431.

PINTO, O.M.O. 1932. Resultados ornithológicos de uma excursão pelo Oeste de São Paulo e Sul de Mato Grosso. Rev. Mus. Paul. 17:689-826.

PINTO, O.M.O. 1940. Nova contribuição a ornitologia de Mato Grosso. Rev. Mus. Paul. 2:1-37.

PIVATTO, M.A.C., MANÇO, D.D.G., STRAUBE, F.C., URBEN-FILHO, A \& MILANO, M. 2006. Aves do Planalto da Bodoquena, Estado do Mato Grosso do Sul (Brasil). Atual. Ornitol.129:1-26.
RIBEIRO, B.A., GOULART, M.F. \& MARINI, M.A. 2002. Aspectos da territorialidade de Knipolegus lophotes (Tyrannidae, Fluvicolinae) em seu período reprodutivo. Ararajuba 10(2):231-235.

RIDGELY, R.S. \& TUDOR, G. 1994. The Birds of South America: The Suboscines Passerines. University of Texas Press, Austin.

RODRIGUES, M., CARRARA, L.A., FARIA, L.P. \& GOMES, H.B. 2005. Aves do Parque Nacional da Serra do Cipó, Minas Gerais, Brasil. Rev. Bras. Zool. 22:326-338. http://dx.doi.org/10.1590/S010181752005000200005

SICK, H. 1997. Ornitologia Brasileira. Nova Fronteira, Rio de Janeiro, 861p.

SIGRIST, T. 2009. Avifauna Brasileira: descrição das espécies. Avisbrasilis, São Paulo, 492p.

SILVA, M.B., ZUCCA, C.F., SOUZA, C.R., MAMEDE, S., PINA, P.I. \& OLIVEIRA, I.R. 2006. Inventário da Avifauna no Complexo AporéSucuriú. In Biodiversidade do Complexo Aporé - Sucuriú: Subsídios à conservação e ao manejo do Cerrado. Área Prioritária 316-Jauru (T.C.S. Pagotto \& P.R. Souza, eds.). Editora UFMS, Campo Grande, 308p., p.113-128.

SILVEIRA, L.F. \& STRAUBE, F.C. 2008. Aves ameaçadas de extinção no Brasil. In: Livro Vermelho da Fauna Brasileira Ameaçada de Extinção (A.B.M. Machado, G.M. Drummond \& A.P. Paglia, eds). Ministério do Meio Ambiente e Fundação Biodiversitas, Belo Horizonte, p.379-666

STRAUBE, F.C., BORNSCHEIN, M.R. \& SCHERER-NETTO, P. 1996. Coletânea da avifauna da região noroeste do estado do Paraná e áreas limítrofes (Brasil). Arq. Biol. Tecnol. 39(1):193-214.

STRAUBE, F.C., URBEN-FILHO, A., ROCHA, M.C.V., NUNES, A.P. \& TOMAS, W.M. 2006. Nova contribuição à Ornitologia do Chaco Brasileiro (Mato Grosso do Sul, Brasil). Atual. Ornitol. 134:1-27.

TUBELIS, D.P. \& TOMAS, W.M. 2003. Bird species of the Pantanal Wetland, Brazil. Ararajuba 11(1):5-37.

WILLIS, E.O. 1976. Similarity of a tyrant-flycatcher and a silky-flycatcher: not all character convergence is competitive mimicry. Condor 78:553-553. http://dx.doi.org/10.2307/1367106

ZUCCA, C.F., ZUCCA, L.S., MARTINS, M.A., ALVES, L.M. \& FONTES, C.Z. 2007. Registro adicional de Laterallus viridis (Rallidae) no estado de Mato Grosso do Sul. Rev. Bras. Ornitol. 15(1):125-126. 